\title{
Modes of Thinking and Language Change: The Loss of Inflexions in Old English
}

\author{
Jesus Martinez del Castillo \\ Department of Philology, Faculty of Business Studies and Tourism, Universidad de Almería, Almería, Spain
}

Email address:

jesus.gerardo@ual.es, apofansis@msn.com

\section{To cite this article:}

Jesus Martinez del Castillo. Modes of Thinking and Language Change: The Loss of Inflexions in Old English. International Journal of Language and Linguistics. Special Issue: Linguistics of Saying. Vol. 3, No. 6-1, 2015, pp. 85-95. doi: 10.11648/j.ij11.s.2015030601.21

\begin{abstract}
The changes known as the loss of inflexions in English $\left(11^{\text {th }}-15^{\text {th }}\right.$ centuries, included $)$ were prompted with the introduction of a new mode of thinking. The mode of thinking, for the Anglo-Saxons, was a dynamic way of conceiving of things. Things were considered events happening. With the contacts of Anglo-Saxons with, first, the Romano-British; second, the introduction of Christianity; and finally with the Norman invasion, their dynamic way of thinking was confronted with the static conception of things coming from the Mediterranean. The history of English from the $11^{\text {th }}$ to the $15^{\text {th }}$ century meant the introduction, confrontation and adoption of a new mental conception of things, the static way of conceiving of things, both modes of thinking defining the language today.
\end{abstract}

Keywords: Modes of Thinking, Modes of Being, Things as Processes, Things as Classes, Idea of Motion, Idea of Place, Idea of Time

\section{Introduction}

The so-called English language, so as it manifests in the present state of the language ${ }^{1}$, is to be characterized, from a diachronical point of view, as an analytic language with some inflexions, prepositions, determiners, numerals, conjunctions, adverbs, nouns, adjectives, different kinds of verbs, a very numerous vocabulary, a complex syntax, a rather simple morphology and a very peculiar sound system. The fact is that the English language can be traced back to times when it was a synthetic language, when it was rightly connected with the so called Germanic languages, in the form of what we today know as Old English. It is peculiar of the language we call English the fact that the separation of it from other cognate Germanic languages and even the re-creation and separation of the different states of the language constituting it, was produced by a series of changes very well defined and exhaustive. These series of changes meant a turning point in the evolution of the language. In this sense you can see three

1 A state of the language is the analogous technique of speaking in force in a particular period of time. A state of the language has an architecture and in every part of that architecture you can find a structure. In the architecture of the language you can find analogous forms. In the structure of the language you can find homogeneous forms. Cf. Martinez del Castillo 2015g, § 5-§ 5.5. periods, every one of these involving several states of the language:

1. the language spoken in Britain since the $5^{\text {th }}$ century up to mid $12^{\text {th }}$ century. This language was a synthetic one with very complex paradigms of inflexions in nouns, verbs, adjectives and word formation. This language was spoken during, roughly speaking, seven centuries. It was to be defined and characterized by a particular mode of thinking, that is, a particular way of conceiving of things and tackling with them. This language is usually known as Old English.

2. The language started changing in the $11^{\text {th }}$ century up to $15^{\text {th }}$ century, included. This period lasted 500 hundred years, usually known as Middle English. In accordance with this, the language spoken in the $11^{\text {th }}$ century and early $12^{\text {th }}$ centuries was still Old English, thus constituting the starting point in the evolution of the language.

The composition of the original text of the Anglo-Saxon Chronicle $^{2}$ finished by 1030 . When in 1080 the Chronicle

2 I am going my to base my analysis on texts of the Anglo-Saxon Chronicle. Old English Annals, Old English Chronicle or the Anglo-Saxon Chronicle, is a set of annals (chronicles) based on the national history of the Old English people when established in Britain. These annals represent the first extended original 
started being copied in monasteries different from the original one, the changes operated during that short period of time were so radical that they let us consider this century and the next one as the turning point in the evolution of the language. The changes usually known as the loss of inflexions started appearing in the $11^{\text {th }}$ and mid $12^{\text {th }}$ centuries and occurred during the whole period now called Middle English. So the Middle English period, however, involved at least four states of the language: the $11^{\text {th }}$ and mid $12^{\text {th }}$ centuries, the Norman period (mid $12^{\text {th }}$ and $13^{\text {th }}$ century, the time when the changes started in the $11^{\text {th }}$ and $12^{\text {th }}$ centuries manifested), the Age of Chaucer $\left(14^{\text {th }}\right.$ century), and the language in the $15^{\text {th }}$ century.

- The changes happened in the late $15^{\text {th }}$ century up to the late $17^{\text {th }}$ century, all occurred around the vowel change called the Great Vowel Shift with the subsequent re-arrangement in all vowels and other elements of the language, thus constituting the Early Modern English period (1476-1700). This period was no longer under the influence of the loss of inflexions. Then a new process of evolution started still in force today, of different character.

\section{The Mode of Thinking of the Anglo-Saxons}

The mode of thinking, for the Anglo-Saxons, was $a$ dynamic way of conceiving of things. Things did not exist: they were considered events happening. With the contacts of the Anglo-Saxons with the Romano-British population, first, and later on with the introduction of Christianity, with one God, an eternal and immovable God, lasting for ever and with no beginning or end" ${ }^{3}$, the concepts explained by "Columba mæsse.prēost" (the Chronicle, Anno 565) were difficult to understand. The introduction of Christian concepts meant the confrontation of two mental conceptions about things, static vs.

composition in English. It was first composed in a monastery around the court of King Alfred the Great and later on copied in other monasteries. There are seven surviving manuscripts. The last annal relates to the year 1154 considered to be the last known document of Old English. As a matter if fact, the so-called Peterborough Chronicle, copied after a fire in the Peterborough monastery in 1116, attests changes having been operated in the text. The copies of the Anglo-Saxon Chronicle coincided during the Norman period.

The Chronicle started being written when the kings of Wessex had got political predominance over the other Anglo-Saxon kings in Britain in one of the dialects spoken at the time, West Saxon. On the other hand, King Alfred ordered to translate all manuscripts previously written in English to West Saxon. In this sense the manuscript still extant of Beowulf, for example, is a mixture of dialects. West Saxon dialect in this sense got cultural predominance over the others. This does not object to the fact that it is not the dialect Modern English is descended from. Henry Sweet (1845-1912) is the first scholar who studied Old English texts.

3 Parmenides of Elea, $6^{\text {th }}$ century B.C. defended this idea applied to being. Being is one, eternal, immobile, it has no beginning or end. Heraclitus of Ephesus, $6^{\text {th }}$ century B.C. as well, defended being in opposition to its contrary. They both took these ideas of their speech community. Later on Aristotle, $4^{\text {th }}$ century B.C. added to this conception of being the idea of substance. The conception of things in this way is usually known after Aristotle, as substantive being. Christian thinkers were born under the influence of substantive being and applied it to their beliefs about God. Cf. Martinez del Castillo 2015j, pp. 77-84. dynamic. Christianity was accepted because it came from Rome, the prestigious and learned center of knowledge coming of old. The acceptance of Christianity brought with it a static mode of thinking, the so-called substantive way of thinking, proper of the Mediterranean tradition, first recorded by the Greek and later on broadcast by all Mediterranean Cultures all round the world. The presence of the Normans in the island in the late $11^{\text {th }}$ century strengthened the new way of thinking.

The loss of inflexions in the English language, a process of changes starting in the $11^{\text {th }}$ century and lasting up to the $15^{\text {th }}$ century, meant the adoption of a new way of conceiving of things, that is, a new mode of thinking. The Anglo-Saxons, who had conceived of things as processes, adopted the static way of thinking of substantive being functioning in Western Europe. The problem was to adapt both ways of thinking thus forming a new one. This adoption was radical enough to affect all the systems in the Old English language. It affected mostly verbs, nouns, adjectives and all elements in a sentence or a phrase.

The so-called weak points in the language constituting the state of the language spoken when the Anglo-Saxon Chronicle was written in the $10^{\text {th }}$ century, sometimes described as irregularities, were the first indicators of the process resumed happening, not started, with the coming of the Anglo-Saxons to the island. This fact may make us conclude, following Coseriu, that language change is something produced internally in speaking and because of speaking. Because of this, language change is to be analysed in terms of the attitude and beliefs of speakers thus constituting their conception of things or their mode of thinking.

I am just going to analyse the mode of thinking in the $10^{\text {th }}$ century, a period of self-confidence for the Anglo-Saxons and opposition to the language brought from the continent, the time of King Alfred, first, and later on period of the Anglo-Saxon Chronicle, copied and updated all around the country. I am going to analyse the weak points in the language, looking for the way of thinking they reveal. The main ideas to be found out now are: the conception of things; things conceived of as events or processes; things as classes; verbs as the expression of processes; the idea of motion vs. rest in verbs and prepositional phrases; the significance of the absence of the indefinite article; the role of correlations in sentences; the appearance of the passive voice, the continuous and perfective tenses; and the value of the adjuncts of place and time.

\section{Vocabulary}

One of the central Christian concepts, "Trinitas", for example, at the beginning was rendered as prines (="something becoming three") and later on as "trinity", something immobile existing for ever, moving anything but not moving itself. The sense of both words was the opposite with each other. Prines was dynamic, trinity static. In the same way, concepts once introduced in the language at the times of the Anglo-Saxons were rendered again at the time of the 
Normans. So technique of writing for the Anglo-Saxons was bōccraeft (book-skill $<\bar{b} \bar{c}+$ croeft), keeping the sense of technique vs. something existing in itself; rimcraft (number-skill), the technique of dominating the numbers; or tungolcraeft (tongue-skill), the technique of dominating speech; stcercrceft (star-skill = the technique of dominating stars). These words were later on abandoned and rendered again with the name brought by the Normans as, respectively, writing, language, grammar and astronomy. These words, from the point of view of the conception of things, were different. They meant something supposed to be. In this process of changing, the Norman period represents the continuation of series of problems posed in a tradition lasting nearly 600 or 700 years, since the Anglo-Saxons established in Britain. The new words introduced (writing, language, grammar and astronomy) meant something "existing", something apart from the agents dominating those skills, static and objective, very similar to natural objects ${ }^{4}$, not the skills involving the human subjects practicing them.

\section{Describing Things as Processes}

From the point of view of the conception of things, Anglo-Saxon lexical verbs are to be divided into two classes, both affecting the same verb the great majority of times. Lexical verbs have two forms, one to be characterized as neutral or non-perfective and the second one as perfective. This distinction, not usually stated in this way, reflects the interests of the Anglo-Saxons in describing facts as processes, either finished or unfinished, that is, describing an action or the result of an action.

Nearly all lexical verbs had this possibility of expression, since the difference in them was marked with a prefix. Prefix $\dot{g}$ e. gives the sense of attainment of the action denoted in the stem of the verb, that is, it has a perfective sense, an action which was successfully achieved after a process. The absence of prefix $\dot{g} \mathrm{e}-$ meant an action, the result of which is not mentioned. For example,

$457^{5}$. Hēr Hengest and $Æ s c$ fuhton wip Brettas

457. Then Hengest and Asc fought against the British.

In this example the action is merely descriptive. It describes something happened. Without a context, we cannot know what the result of the battle was. The result on the contrary is clear in the following example,

473. Hēr Hengest and Æsc ge.fuhton wip Wēalas

473. Then Hengest and Ash successfully fought against the Celts (who were defeated).

That is, the same verb has a double use, a non-perfective

\footnotetext{
4 Take for example language. As a matter of fact, some speakers today conceive of language, as something natural, innate and objective existing in it. Cf. Martínez del Castillo 2015j, § 3 .

5 Annals are usually referred to with the Latin expression 'Anno': Anno Feower hund and fiftig-nigon. Some examples here will be commented several times depending on the aspect discussed.
}

descriptive sense, and a perfective sense stressing the result of the action performed. In the second example the idea of motion is stressed, something going beyond the facts stated.

867. And hīe late on geare tō pǽm ġe.ciierdon pæt hīe wip pone here winnende wǽron

867. And they late in the year submitted to them because they [these ones] were winning with the army [they had].

The action of submitting someone is an action needing both the action in itself and then finishing that action. Verb cierran is usually used with the prefix, ge.cierran, something known traditionally but said in the use of the verb.

Because of this grammatical device, some verbs in Old English can have two meanings. So you have feohtan and ge.feohtan, just illustrated in the examples above, gān and ge.gān meaning respectively 'go' and 'conquer'; winnan and ge.winnan, 'win' and 'succeed in winning'; bindan and ge.bindan, 'bind' and 'succeed in binding'; etc.

With the pass of time, the expression with $\dot{g} e$. became redundant as in bindan / ge.bindan, and particularly in seōn / $\dot{g}$ e.seōn, see, and hieran / ge.hieran, hear. The prefix was particularly used in past participle thus stressing the function of this verb form, ge.cweden, from cwepan, 'say', ge.cwepan, 'name'.

Prefix $\dot{g}$ e. appears as well with nouns denoting a complex action, gंe.work, 'military work', ge.writ, letter, ge.fèra, companion, ġe.lē $a f a$, belief, $\dot{g} \mathrm{e} . r \overline{\mathrm{e}} f a$, reeve, $\dot{\mathrm{e}}$ e.wuna, habit. That is and said paraphrasing the words in the examples, ge.work is the work previously planned and then executed; $\dot{g}$ e.writ, writing in as much as it has already been written; a $\dot{g}$ e.fèra is someone who is an associate of another or others; a $\dot{g}$ e. $r \overline{\mathrm{e}} f a$ is someone taking control of something in the name of the king; ge.wuna is in connection with wunian, dwell; a ge.wuna is something you live with, a habit or a custom. In some way or another the idea of motion and its contrary, rest, are present in these words, that is, they mean processes already finished.

The presence of prefix $\dot{g} e$. in Old English has to do with the conception of things. As we shall see in the next paragraph the function of verbs is not to describe but to denote something happening, that is, expressing the idea of motion thus denying the contrary, the idea of rest. The contacts of Anglo-Saxons with the Celtic-Roman people, the mental confrontation and acceptance of Christianity, and the coexistence with the Normans, meant changing their conception of things. Anglo-Saxons verbs denoted finished or unfinished processes, that is, they described events in their performance. With the new mode of thinking they had to re-state the meaning of their verbs, which in principle did not disappear, but gradually omitted their use as something finished thus annulling the distinction based on prefix $\dot{g} e$.

Prefix $\dot{g} e$.- disappeared by the end of the Middle English period. However the function performed by it still prevails as a syntactic use in examples such as the tyres are worn flat. The disappearance of prefix ge.- is to be related with the appearance of the passive voice, the continuous and perfect tenses. These were very adequate to describe things either in 
progress or in a static way.

The idea of motion in verbs did not disappear in the language. In Modern English it appeared in a new sense in the so-called prepositional verbs and phrasal verbs. Take for example verb $d o$. Do primarily means "to perform and finish an activity". This action can be orientated in terms of the preposition or particle it is followed with. The following uses illustrate this: to do away with (for example, he did away with the deal successfully), do down (for example, he'll do you down, if he can), do for (for example, he can't do anything else: he's done for), etc. That is, the activity meant by the verb is determined in terms of the content of the preposition in a particular way thus involving the idea of motion.

\section{Things Existing as Classes}

For an Anglo-Saxon, to conceive of something meant describing the process in which it was given. Things then were not entities but classes of things and thus events or processes, they did not mean individual things. Because of this, the indefinite article was not necessary. Individualization of things started appearing in the early $13^{\text {th }}$ century. The following example is very illustrative

sē his hüs ofer stān ġe.timbrode.

who built his house on rock ${ }^{6}$.

The author of this sentence did not speak of a particular rock but of the class of rocks; because of this the example is in the singular. The translation of this example by Sweet uses the indefinite determiner $a$, because in the way of thinking of English today it is necessary to specify that it was in the singular, a particular rock, not the class, in which all rocks were included.

In the Anglo-Saxon Chronicle however there appears what may be considered one the first appearances of the indefinite article with the numeral $\bar{a} n$ :

501. and [hīe] of.slōgon ānne geongne Brettiscne mannan, swīpe æpelne.

501. And they killed a young British man who was very important.

Anne in the example is not a determiner because on the contrary the adjectives following the numeral would be in the weak declension. It is a numeral. Anyway this type of construction in the text, represents a necessity of expression in the language at the time ( $11^{\text {th }}$ century).

\section{No Towns or Countries But People}

For the Anglo-Saxons, nuclei of population were not places, that is, towns, regions or even kingdoms, but groups of people living together. The places occupied by them were not mentioned:

6 Cf. Sweet, 1970, p. 56-57.
449. Se cyning hēt hīe feohtan on.ġean Peohtas; and hīe swā dydon and sige hæfdon swā hwær swā hīe cōmon.

449. The King ordered them to fight against the Picts; and they did so and had victory wherever they went.

However they were dealt with as if they were places: "swā hwær swā hīe cōmon"7 . The famous kingdom of Northumbria was referred to in the same way:

449. Of Angle cōmon -sē ā sippan stōd wēste betwix Īotum and Seaxum-Ēast.engle, Middel.engle, Mierće and ealle Norp.hymbre

449. From the land of Angles (on the continent) - which has ever stood desolate between the Jutes and the SaxonsEast Angles, Midlanders, Mercians and all people of Northumberland came.

As we saw in $\S 5$, words did not mean individual things but classes of things. In order to refer to individual things it is necessary to use determiners. For the Anglo-Saxons, this procedure was not necessary: it is not *'betwix pém Iotum' or * 'pā Miercie', but simply 'betwix Iotum' or 'Mierće'. The class had predominance over the individual thing.

\section{Verbs Bēon/Wessan and Weorban and the Passive}

The passive voice as such had previously existed in the language, the only extant form in Old English was hâtte from hâtan, 'call', 'name'. In the language spoken in Britain from the $5^{\text {th }}$ to the $12^{\text {th }}$ centuries, the passive voice was not used. According to Sweet there existed the possibility of forming the passive periphrastically with verbs wessan and weorban but he adds: "These forms are very vague in meaning" $"$. The reason of this is that the passive voice in the conception of things by the Anglo-Saxons was unnecessary. As we saw in $\S$ 3 and shall confirm in $\S 7$, the mode of thinking by the Anglo-Saxons was expressing things in the process they were conceived of. For them, there were no things existing in themselves standing in front of us $(\S 4)$, but processes that should be developed in order to understand them. In this sense the passive voice, the transformation of the perspective in accordance with the way things are considered, stressed or emphasized, was meaningless to them. The idea of motion in contraposition to the idea of rest was much more significant.

For Westerners, the most representative idea is conceiving of things existing in themselves and consequently the most representative verb in their thought is verb $b e$. This constitutes the so-called substantive-being or substantive mode of thinking. For the Anglo-Saxons, the most representative idea was motion as opposed to rest, and the most representative verb, weorpan (become, happen), that is, their mode of thinking constituted conceiving of things as becoming, as

\footnotetext{
7 This use appears in the expression of time as well (cf. $\S \S 7.3-7.5$ ).

8 Sweet 1970, p. 53
} 
events in a process ${ }^{9}$.

The passive voice re-appeared in the language at the end of the period called Middle English, that is, it appeared when the process described here was near to an end and prefix $\dot{g} e$. had disappeared. That is, a process disappeared and was superseded by another one to a certain extent similar. The passive voice emphasizes the object (direct or indirect) rather than the subject of an action as it is finished, something to a certain extent expressed in Old English with prefix $\dot{g} e$. (cf. § 4) and the idea of motion.

\subsection{The Idea of Motion: Prepositional Phrases}

For an Anglo-Saxon, it was fundamental to conceive of things in connection with the development of an action, that is, a process. A process must indicate motion or the opposite, rest. Verbs constitute the main element in a sentence. The main idea always born in the mind in the conception of things was the idea of motion, the development of it, and the contrary, the negation of it. This fact can be seen in sentences, particularly in prepositional phrases. Prepositional phrases constitute elements clearly manifesting the idea of motion, expressed with the verb.

Old English was a synthetic language in which all words were defined in terms of the syntactic function they performed in a sentence or phrase. Prepositions could govern different cases. Some could govern the accusative, some the dative, some the instrumental case. The most frequent use is that they should govern the accusative when the idea of motion was involved or the dative case when rest was implied. Prepositions are used in this way, to express the opposition motion-rest. All other aspects prepositions can convey are subordinated to this one. In the Anglo-Saxon Chronicle, $11^{\text {th }}$ century, you can see the following uses.

\subsection{Preposition Wip and Mid with the Dative or the Accusative}

Preposition wip governed the general rule thus involving motion or the contrary rest.

457. Hēr Hengest and Æsc fuhton wip Brettas (motion involved thus the accusative)

457. Then Hengest and Asc fought against the British [=the Roman Celts].

473. Hēr Hengest and Æssc ge.fuhton wip Wēalas (motion involved)

473. Then Hengest and Ash fought against the Celts.

The idea of motion in the last example makes interpret the

9 Ortega y Gasset says: "The most characteristic expression of the Hellenic concept of being is being as a substance, immobile and invariable. Even in the ultimate substance, the beginning of all change and movement, in the Aristotelian God, you can find an Entity moving anything but not moving Itself" (Obras completas, VII, p. 339; my translation)". For the role of verb be in Greek and other languages, cf. Benveniste, 2007, vol. I, p. 71-72). And finally for a discussion about language and the mode of thinking, cf. Martínez del Castillo 2013. preposition in a particular way. The sense of the prepositional phrase is to be rendered as 'against', an idea stressed as well with the presence of prefix -ge.

867. And hīe late on gēeare tō pǽm gae.ciierdon pæt hīe wip pone here winnende wǽron (motion involved as well but the dative).

867. And they late in the year submitted to them because they [these ones] were winning with the army [they had].

Verb cierran, involving a process because of prefix ge-, conveys the idea of something finished. The expression of motion is expressed with the verb, but it governs the dative because the result of the battle stresses a new state of affairs in which rest is involved.

495. Hēr cōmon twēgen ealdor.menn on Bretene, Cerdic and Cynrīc his sunu, mid fîf scipum, in pone stede pe is ge.cweden Cerdices.ōra; and pý ilcan dæge ge.fuhton wip Wealum (motion is involved but the dative).

495. Then two chiefmen came to Britain Cerdic and Cynrīं with five ships in the place that is called Cerdices.ōra; and that very day, they succeeded in their fight against the Celts [who were defeated].

In this example, preposition wip governs the dative in spite of the active character of verb feohtan, 'fight'. The reason of this is that feohtan is used in the finished function with prefix ge-. So both clues of meaning are to be stressed: they fought against the Celts and won. The fight was over and the victory certain. The preposition governs the dative because the action was expressed at a time when the victory was certain to have happened.

Comparison with these examples reveals that the rule concerning all prepositions functioning at the time, had a stylistic value going beyond the meaning of the verb and the grammar of the words involved thus constituting a weak point the system of the language at the time.

On the other hand, preposition mid, now extant in the language as a prefix, appears but governing the dative. The adjunct expressed with preposition mid is not affected with the action expressed with the verb cuman (come), especially when the adjunct is introduced in the instrumental case. The instrumental case was a remnant of previous states of the language in Old English.

851. Hēr Ċeorl ealdormann gefeaht wip hǽpne menn mid Defena.scīre æt Wicganbeorge (both involving motion thus the accusative).

851. Then the chief-man Ceorl fought against the heathen (the Danes) together with the Devon army at Wicganbeorg.

In this example both the idea of motion, with the accusative, and the idea of collaboration with the accusative as well are introduced. Preposition mid was associated with a case no longer existing, the instrumental case, thus introducing an instrumental value in the sentence. The central idea is the idea of motion.

Both prepositions mid and wip would later on coalesce in 
preposition wip.

\subsection{Preposition On and Ofer and the Idea of Place as Part of a Process}

With the accusative, preposition on means 'into', but with the dative it means 'in'. That is, the idea of motion prevails. Due to the meaning of the verb the idea of rest may be interpreted as meaning place. It is the case of verbs such as standan (stand) or eardian (inhabit) or nouns such as stede (place).

853. and pǽr wearp manig mann of.slæg்en and ā.druncen on $\dot{g}$ e.hwæpere hand= (the accusative case, thus the idea of motion, not place).

853. And there happened that many men became killed and drowned on both sides.

The sentence is governed by verb wearpan (also spelt weorpan=become), a verb playing the function very similar to bēon (cf. § 7). Both weorpan and bēon denote the existence of something but with a difference: bēon is static, but wearpan is dynamic. With this we can see that bēon denotes a state but wearpan a process. So if the author used the accusative it is because he was thinking of the process in the verb.

On the other hand, the object of wearp is in the singular, that is, it gives the idea of a class of objects, the class mann, thus meaning many a man. As we said above (cf. $\S 5$ ), in the Anglo-Saxon way of thinking the class was predominant over the particular thing referred.

855. And ymb twā gēar pæs pe hē on Francum cōm, hē ge.fōr.

855. And it was about one year that he had come from the land of the Francs that he died.

The preposition on governs its object, Francum, thus expressing rest instead of motion. Literally: "and about two years after he had been in the land of the Francs, he died". The author says cōm instead of wæs, but his intention was to state the moment when he had been away. That is, if he had stayed a bit longer in the land of the Francs he could have died there.

So in the time of the Anglo-Saxons the mode of thinking was that things happened but did not exist. That is, their mode of thinking was not the static conception transmitted from the times of the Greek in the so-called the substantive being ${ }^{10}$, but a dynamic way of thinking. Things were conceived of as events happening, not as states. In this sense the ideas of place and time were not directly expressed with these prepositions. The idea of place would later on be introduced in the language with preposition in. The idea of place was not the most adequate to the mode of thinking of the Anglo-Saxons. Things in the new mode of thinking will be states and because of this, they must be specified in the circumstances they are affected with, one of them is the place where they are; and the other one, is the time when they, do not happen, but are, that is, when things are fixed in being.

In present day English the following examples have to do with the expression of place but in Old English they had to do with motion:

853. and mid fierde fōr ofer Mierće on Norp.wēalas and hie him ealle $\dot{g}$ e.hiersume dydon (motion thus the accusative in both cases)

853. And with an army he went into Mercia against the Northern Celts [the people in Wales] and they succeeded in making them subjects.

But preposition ofer is governed with a verb of motion, faran (go), thus introducing a dynamic context. This context is very adequate to preposition on thus governing the accusative (to be translated as against). Henry Sweet (1845-1912) interprets the following example as expressing place:

sē his hūs ofer stān ge.timbrode.

who built his house on a rock.

Sweet, who explains the use of Old English prepositions in the way stated above, merely explains the use: the accusative when it is governed with the idea of motion, and the dative when the idea of rest is involved. In many examples Sweet cannot find an explanation and accepts them merely as exceptions. However, when he comments this example gives the right explanation of it. He says: "the acc. stān may be accounted for by considering the process of building rather than the completed state" 11 . That is, the problem was the opposition between motion and rest. For the minds of Old English speakers, it was impossible to conceive of things statically. The expression of place has to do with the idea of rest. But most Old English verbs and thus the contexts of innumerable sentences, stressed the idea of dynamism. The right translation of the sentence then would be something like, "he who built his house on rock" meaning with it that the house was firmly based on rock, the contrary to a house built on sand.

The following example seems to express place, since one of the uses of $o n$ is in the dative.

449. And on hiera dagum Hengest and Horsa, fram Wyrtgeorne ġe.lapode, Bretta cyninge, ge.sōhton Bretene on pǽm stede pe is ge.nemned Ypwines.flēot, ǽrest Brettum tō fultume, ac hīe eft on hīe fuhton.

449. An on their days Hengest and Horsa, invited by Wyrtgeorn, the king of the British, reached Britain in the place that is called Ebbsfleet, just before some one should help the British, and they immediately fought with each other.

In this example on appears three times, the two first, to express rest (with the dative); and the third, to express the idea of motion, in the accusative. The two first examples can be interpreted as the expression of time and place, with the dative, thus appearing as something apart, that is, as something not 
directly governed by the verb or under the direct influence of the verb. In the third use, preposition on, under the influence of the verb, governs the accusative and thus the expression of the idea of motion.

449. Of Īotum cōmon Cant.ware and Wiht.ware -pæt is sēo mǽg̀jp pe nū eardap on Wiht- and pæt cynn on West.seaxum pe man nū giēt hǽtt 'Īotena cynn'.

449. Of the [the land of the] Jutes [on the continent] the inhabitants of Kent and Whit came - because that is the family which now lives in Whit - and the nation living in Wessex which now are still called the 'the tribe of the Juts'.

Here preposition on appears twice, both in connection with the idea of rest (with the dative). The idea of rest appears as well in the verb eardian (inhabit), a verb in connection with standan (stand), both meaning not an action but a static state of affairs. So the cause of the presence of the dative in both cases is the character of the verb. There is then no expression of place.

Examples with ofer:

855. And pý ilcan gēare ge.bōcode Æpelwulf cyning tēopan dǽl his landes ofer eall his rïce Gode tō lofe.

855. And that year king Æpelwulf published a grant giving the tenth part of his land all over his kingdom to the glory of God.

$\dot{G}$ e.bocian is an active verb. It describes the action of granting something published in a chart, that is, giving something and making it public and notorious. So the underlying conception is that something is to be executed in something else. $\dot{G}$ e.bocian, on the other hand, denotes an action already performed in something else. At the same time it is a transitive verb, that is, the action denoted with it, has to be executed in the noun phrase governed with the verb, thus in the accusative case, tēopan dǽl his landes ofer eall his rice (the tenth of his land all over his kingdom). The only interpretation possible is based on the dynamic character of the action.

867. Hēr fōr se here of Ēast.englum ofer Hymbre.mūpan tō Eoforwic.ceastre on Norb.hymbre.

867. Then the army went from the land of Essex to the estuary of river Humber to York against the Northumbrians.

Ofer in the example clearly stresses the idea of motion in the verb faran. In this sense the function of preposition ofer is very similar to the one of the following preposition tō.

Preposition on appears as well in its original function of expressing motion, on Norb.hymbre, a proper name, masculine plural, in the accusative, 'against the Northumbrians'. Verb faran governs the whole sentence.

\subsection{The Idea of Place: Preposition in}

The idea of motion/rest in some way or another was always present in the use of on and ofer. Because of this the ideas of place and time, so important after the $12^{\text {th }}$ century, were of little interest in the period. The idea of place appeared with preposition in, which was very seldom used in contraposition with on and ofer:

455. Hēr Hengest and Horsa fuhton wip Wyrtgeorne pǽm cyninge in pǽre stōwe pe is ġe.cweden Æglēs.prep.

455. Then Hengest and Horsa fought with King Wyrtgeorne in the place which is called Ebbsfleet.

In this example the idea of place is clearly expressed, first with preposition in, and second, with the expression of the word stōwe. But the idea of motion is expressed as well in the verb the influence of which does not affect the expression of time.

The same procedure is expressed in

457. Hēr Hengest and Æsc fuhton wip Brettas in pǽre stōwe be is $\dot{g}$ e.cweden Crecgan.ford.

457. Then Hengest and Ash fought against the British in the place which is called Crayford.

495. Hēr cōmon twēgen ealdor.menn on Bretene, Cerdic and Cynrīic his sunu, mid fîf scipum, in pone stede pe is ge.cweden Cerdices.ōra;

495. Then two chief-men came in Britain, Cerdic and Cynrīic his son, with five ships, in the place which is called the Banks of Cerdic.

501. Hēr cōm Port on Bretene and his twēgen suna Bieda and Mægla, mid twǽm scipum, in pā stōwe pe is ġe.cweden Portes mūpa.

501. Then Port came to Britain along with his two sons Bieda a Magla, with five ships, in the place that is called Portsmouth.

The first example, with preposition in, governs the dative, and second and third ones, the accusative. That is, the first on has to do with the idea of rest, something that can be connected with the idea of place, but the second and third ones strengthen the idea of motion, something contrary to the idea of place. That is and said in other words: the expression of motion was something with no connection with the expression of place.

At the same time it is interesting to realize that in all examples with in, apart from governing the dative or the accusative, they are accompanied with the specification of the head of the prepositional phrase (stōw and stede, both meaning place with small differences: stōw can be said of place in general, a passage in a book, for example; and stede, just meaning place). This fact, for me, means that the use with preposition in was not firmly established in the language at the time, because it was an exception in the concept it denoted, being motion the real thing to be expressed with nearly all verbs. The use of both the dative and the specification of the object of the preposition in, means repeating the same idea: it was not enough to use preposition in only.

The following example may show instability of the general rule said above:

514. Hēr cōmon West.seaxe in Bretene, mid prim scipum 
in $\mathrm{p} \bar{a}$ stōwe pe is $\dot{g}$ e.cweden Cerdices.ōra. and Stuf and Wihtgār fuhton wip Brettas and hīe ge.flīemdon.

514. Then the West Saxons [on the continent] came to Britain, with three ships in the place that is called Cerdic.shore; and Stuff and Whitgār fought against the British and they [the British, that is, the Celts] were put to flight.

This example can make us conclude about the problems posed so far. The idea of motion is present in verb cuman or ge.cuman; the expression of place with in, needs specification but that specification governs the accusative, because of the influence of the idea of motion in the verb.

The expression of place in Old English may be considered to have started with the dative. Since the presence of the idea of motion was very strong as clues of meaning added in nearly all verbs. The expression of the contrary, the idea of rest, in connection with the idea of place, was neglected especially when the verb governed the accusative. In order to introduce the idea of place within the sphere of verbs of motion it was necessary to specify the sense of it. On the other hand, words meaning place such as stede, in connection with verb standan, 'stand', and stow, 'place', were very appropriate since both introduced the idea of rest. The idea of motion constituted the usual way of thinking, the underlying mode of thinking in Old English, but the idea of place was in direct opposition to the expressive interests of the Anglo-Saxons.

\subsection{Prepositions On and Ofer and the Idea of Time}

As I said, the idea of time is possible with prepositions on and ofer because the adjunct of time is not affected with the idea of motion and viceversa. In this sense the expression of time appears as something apart with respect to the action denoted by the verb.

449. Hēr Martiānus and Valentīnus on.fēngon rīce and rīcsodon seofon winter. And on hiera dagum Hengest and Horsa, fram Wyrtgeorne ge.lapode, Bretta cyninge, ge.sōhton Bretene on pǽm stede pe is ge.nemned Ypwines.flēot.

449. Then Martianus and Valentinus took power and reigned for seven years. And on their days Hengest and Horsa, invited by Wyrtgeorn, the king of the British, reached Britain in the place that is called Ebbsfleet.

Here we have the idea of time expressed with preposition on and the dative.

865. se here hine on niht ūp bestæl and ofer.hergode ealle Cent ēastevearde.

865. The army went up against him furtively during the night and ravaged all over the eastern end of Kent.

Preposition on stresses the idea of motion denoted by the verb be.stellan, but that idea does not affect the adjunct of time with on.

\section{Evolution in the Loss of Inflexions}

I said above that the period known as Middle English, the period when the changes affecting the loss of inflexions occurred, you could distinguish four states of the language: the initial language spoken in the $11^{\text {th }}$ and mid $12^{\text {th }}$ centuries, the language spoken in the $13^{\text {th }}, 14^{\text {th }}$ and $15^{\text {th }}$ centuries. Now we are going to comment texts of the $13^{\text {th }}, 14^{\text {th }}$, and $15^{\text {th }}$ centuries.

\subsection{The Language in the $13^{\text {th }}$ Century}

The Fox and the Wolf ${ }^{2}$

A vox gon out of pe wode go

Afingret so pat him wes wo

He nes neuere in none wise

afingret erour half so swipe.

He ne hoeld nouper wey ne strete

For him wes lop men to mete.

Him were leuere meten one hen

pen half an oundred wimmen.

He strok swipe oueral

So pat he ofsei ane wal.

Wipinne pe walle wes on hous.

The wox wes pider swipe wous

For he pohute his hounger aquenche

Oper mid mete oper mid drunche.

A fox gone out of the woods would go

So hungry that he was miserable

He had never been in such a way

As hungry, before, half as he was.

He did not go through any way or street

Since for him it was loathsome to meet people.

For him it was more bearable to meet one hen

Than the half of one hundred women.

He would go anywhere

So that he saw a wall in the distance.

Within the wall a house was

The wolf-fox was there very miserable

For he thought to quench his hunger

Either with meat or with drink.

\subsection{Relevant Facts in the Evolution of the Language in Connection with Thought}

The indefinite article. As we saw the indefinite article determines nouns in such a way that makes them to denote, not the class of objects, but a particular individual object. The indefinite object was introduced in the language at this time. In the poem there appears only an indefinite individual object, A vox. There appear as well nouns denoting classes of objects, wimmin, lop, men, mete, drunche.

The indefinite article was formed with the Old English numeral $\bar{a} n$, thus appearing in different forms, the reduced form $a$ (a vox), ane (ane wal); and even in the Northern variety one (one hen) and on (on hous). In connection with this, the numeral

12 Written in the early $13^{\text {th }}$ century in a Southern dialect. 
an (an oundred wimmen) appears. The means to determine the noun was the numeral. The numeral had a very effective individualizing and determining effect on the noun. But the effect of this use was that the noun did not denote the class of foxes, walls, hens and houses, but an individual item of the class of foxes, walls, hens or houses. It is interesting to remark that in the text the numeral an (an oundred wimmen) is used with the same form as the newly introduced determiner. At the same time the old procedure of nouns referring the class appears several times, lop, men, wimmen, mete, drunche, wo.

Since this individualizing and determining effect was new, the function of the now called definite determiner, $p e$ (reduced from $s \bar{e}, s \bar{e} o$, paet + the ending of $s \bar{e}<\mathrm{p}+\overline{\mathrm{e}})$, was redefined in its function together with nouns denoting classes. Nouns with the indefinite article denote individual objects; nouns with the definite article are determined to reduce their potentiality of designation, and nouns with no determiner denote mass nouns. In the poem there appears only one noun with the determiner, $p e$ wode, nouns denoting the class, lop, men and wimmen, and nouns denoting mass nouns, mete and drunche. This distinction, to be the rule later on, was the effect of introducing the numeral as the instrument to individualize and particularize the noun thus forming the new determiner.

In the text the subjunctive appears in go ( $A$ vox gon out of pe wode go (from gān); gon comes from the past participle gangiende), to indicate that it was about an object of thought not a real object, something very frequent in Old English.

Since particular individualizing and determining objects have been created with the indefinite article, multiple negation appears (He nes neuere in none wise). In Old English, since you spoke of classes of objects, multiple negation was unnecessary In the paragraph, the same as with Old English, negation contracted with the most usual forms of the verb and indefinite pronouns.

Apart from this it is worth mentioning the influence of French in pronunciation, in oundred. This means that the Anglo-Saxons, since they had accepted the mode of thinking singularizing and particularizing things, accepted some features having to do the pronunciation of words. However so far, at this period, they had not accepted anything having to do with vocabulary, something to come after this moment on.

\subsection{The Language in the $14^{\text {th }}$ Century}

\section{The General Prologue to The Canterbury Tales ${ }^{13}$}

Whan that April with his showres soote

The droughte of March hath perced to the roote,

And bathed every veine in swich licour,

Of which vertu engendered is the flowr;

Whan Zephyrus eek with his sweete breeth

Inspired hath in every holt and heeth

The tendre croppes and the yonge sonne

Hath in the Ram his halve cours yronne,

And smale fowles maken melodye

13 Written in the so-called London English dialect.
That sleepen al the night with open yë-

So priketh hem Nature in hir corages-

Thanne longen folk to goon on pilgrimages,

And palmeres for to seeken straunge strondes

To ferne halwes, couthe in sondry londes;

And specially from every shires ende

Of Engelond to Canterbury they wende,

The holy blisful martyr for to seeke

That hem hath holpen whan that they were seke.

Bifel that in that seson on a day,

In Southwerk at the Tabard as I lay,

Redy to wenden on my pilgrimage

To Canterbury with ful devout corage,

At night was come into that hostelrye

Well nine and twenty in a compaignye

Of sondry folk, by aventure yfalle

In fellaweshipe and pilgrimes were they alle

That toward Canterbury wolden ride.

The chambres and the stables were wide,

And shortly, whan the sonne was to reste,

So hadde I spoken with hem everchoon

That I was of hir felaweshipe anoon,

And made forward erly for to rise,

To take oure way ther as I you devise.

But nathelees, whil I have time and space,

Er that I ferther in this tale pace,

Me thinketh it accordant to resoun

To telle you al the condicioun

Of eech of hem, so as it seemed me,

And whiche they were and of what degree,

And eek in what array that they were inne:

And at a knight thanne wol I first biginne.

\subsection{Relevant Facts in the Poem in Connection with Thought}

In connection with thought, the most relevant fact in the poem is still the use of prefix -ge with verbs, yronne, yfalle, but in the past participle, now existing as a stylistic means of expression coexisting with the use of the past participle without prefix ge-, inspired hath [...] the tendre croppes, The droughte of March hath perced to the roote. That is, in the new conception of things, things in as much as they stand in front of us, existing in themselves, can have finished and unfinished processes both coexisting side by side. As a matter of fact, at the end of the Middle English period, perfect tenses were firmly established, the means of expression to express finished and unfinished uses of verbs. Even more: actions could be developed as well as in progress, that is, in progressive forms and considered from different points of view, the passive voice, means of expression introduced as well.

The acceptance of the new conception of things as something objective and existing in them made easier to accept French words than earlier. That is, about three hundred years after the coming of the French invaders, the presence of French words was accepted without any discussion, something did not occur just at the beginning. This involved a fact new to the language: the adoption of French words did not mean rejecting or superseding Anglo-Saxon words. It is the case of chambres 
instead of rooms, in the text. This fact reveals the acceptance of a new mode of thinking, that static one, and at the same time keeping the old dynamic way of thinking.

\subsection{The Language of the Scotts in the $14^{\text {th }}$ Century}

\author{
The Praise of Freedom ${ }^{14}$ \\ A fredome is a noble thing \\ Fredome mays man to haiff liking \\ Fredome all solace to man giffis \\ He levys at es yat frely levys \\ A noble hart may haiff nane es \\ Na ellys nocht yat may him ples \\ Gyff fredome failghe, for fre liking \\ Is gharnyt our all over thing. \\ Ne he yat ay has levyt fre \\ May nacht knaw weill the propyrte \\ Ye angyr na ye wrechyt dome \\ Yat is cowplyt to foule thyrldome \\ Bot gyff he had assayit it.
}

(Word-for-word Translation)

\author{
Ah! Freedom is a noble thing \\ Freedom may make men to have election \\ Freedom gives men all rest \\ He who lives at ease, freely lives \\ A noble heart may have no ease (peace) \\ Or anything else that may please him \\ If freedom fails, for free election \\ Is yearned over all other things. \\ He who certainly has lived free \\ May not know the property at all \\ The anger or the misery \\ That is, together with the base slavery, \\ Unless he had assayed it.
}

\subsection{Relevant Facts in the Poem}

I am introducing this poem to stress the significance it has in the way of thinking of Scotts, in contrast with the previous one. The poem is in a variety of English in the $14^{\text {th }}$ century, Scott English, called Inglis, at the time. It was written by a Scottish priest and directed to Scottish people. That is, it is written by and aimed to people who had had the direct influence of the Romans and Christianity thus preserving their primitive way of thinking apart from the Anglo-Saxons', although they had accepted the language coming form South. My purpose in introducing this poem is comparing the different degree of abstraction manifest in this text, as different from the other texts.

The poem speaks of something considered to exist in it objectively. In this sense it constitutes an object of saying ${ }^{15}$,

14 This poem, belonging to a Northern variety of Middle English, spoken in the Lowlands, called Inglis at the time, was written about 1375, by John Barbour, the Archdeacon of Aberdeen, who had studied and taught in Oxford and Paris.

15 In linguistics of saying, the object of saying is the aspect, underlined or not something worth considering in itself, freedom. For a westerner, someone who conceives of things as if they existed in them objectively and constituted something there in front of you, freedom exists and is there challenging us to attain it. Fredome is an abstract word occupying the highest degree of abstraction, just the contrary of concrete things such as vox, house, hen, etc. Other abstract concepts in the poem, solace, fre liking, es, angyr, wretchyd dome, and thryldome, have a very high degree of abstraction as well. That is, these are the concepts the Scottish of the time could manipulate mentally, not yet the Anglo-Saxons. The Scottish had accepted the language coming of South but kept the way of thinking of their own.

\section{Conclusion}

Language change is nothing but the behavior of speakers who speak because they have something to say, who say because they are able to know, and who know because they conceive of things in a particular way. The conception of things, something learnt by speakers from the tradition in the technique of speaking, constitutes such a radical attitude in them that it determines the mode of thinking in force in a speech community, their historical way of thinking.

The series of changes known as the loss of inflexions, meant nothing but a change in the mode of thinking of the Anglo-Saxons who, conceiving of things as events and classes, started considering them as something existing in them, something in front of speakers, existing in them objectively, confronting speakers either to benefit form them or reject them. This fact can help us understand the depth of the changes operated in the language in the period between $11^{\text {th }}-15^{\text {th }}$ centuries.

\section{References}

[1] Barber, Charles. 1995 (1993), The English Language: A Historical Introduction, Cambridge University Press.

[2] Baugh, Albert C, 1971 (1951), A History of the English Language, London: Rutledge \& Kegan Paul Ltd.

[3] Benveniste, Emile, Problemas de lingüística general, Siglo XXI Ediciones, ${ }^{24} 2007$ [1971], vol. I, p. 71-72

[4] Blake, N, 1996, A History of the English Language, Macmillan.

[5] Bosworht, J, 1995 (1898), An Anglo-Saxon Dictionary: Based on the Manuscript Collections of Joseph Bosworth, T, Northcote Toller, ed. Oxford University Press.

[6] Burchfield, Robert, 1985, The English Language, Oxford \& New York: Oxford University Press.

[7] Cambridge University Press. The Cambridge History of the English Language, 6 volumes, Cambridge University Press.

grammatically, because of which the expression is formulated. It constitutes the final purpose of the utterance. Cf. Martínez del Castillo 2015b, p. 5. 
[8] Coseriu, Eugenio, 1985 [1977], El hombre y su lenguaje, Madrid: Gredos.

[9] Coseriu, Eugenio, 1987 (1978), Gramática, semántica, universales, Madrid: Gredos.

[10] Coseriu, Eugenio, 1988 (1957), Sincronía, diacronía e historia: el problema del cambio lingüístico, Madrid: Gredos.

[11] Coseriu, Eugenio, 1992 (1988), La competencia lingüística, Madrid: Gredos.

[12] Freeborn, Denis, 1992, From Old English to Standard English: A Course Book in Language Variation across Time, Macmillan: Studies in English Language.

[13] Freeborn, Denis, 1996, Style: Text Analysis and Linguistic Criticism, Macmillan: Studies in English Language.

[14] Martínez del Castillo, Jesús, 2006, Facts of Speech and Facts of Evolution: An Interpretation to the History of the English Language, Abecedario.

[15] Martínez del Castillo, 2012, Psicología, lenguaje y libertad, in Analecta Malacitana, Universidad de Málaga, Anejos/89.

[16] Martínez del Castillo, Jesús, 2013a, Modes of Thinking, Language and Linguistics, in Analecta Malacitana, Universidad de Málaga, Anejos/95.

[17] Martínez del Castillo, Jesús. 2013b. English Semantics and Lexicology. Universidad de Almeria.

[18] Martinez del Castillo, Jesús. 2015a. Linguistics of Saying. Presentation. International Journal of Language and Linguistics. Special Issue: Linguistics of Saying. Vol. 3, No. 6-1, 2015, pp. $1-4$.

[19] Martinez del Castillo, Jesús. 2015b. The Meaningful Intentional Purpose of the Individual Speaker. International Journal of Language and Linguistics. Special Issue: Linguistics of Saying. Vol. 3, No. 6-1, 2015, pp. 5-10.

[20] Martinez del Castillo, Jesús. 2015c. The Process of Abstraction in the Creation of Meanings. International Journal of Language and Linguistics. Special Issue: Linguistics of Saying. Vol. 3, No 6-1, 2015, pp. 11-23.

[21] Martinez del Castillo, Jesús. 2015d. Fixing the Construct Created in the Act of Knowing. International Journal of Language and Linguistics. Special Issue: Linguistics of Saying. Vol. 3, No. 6-1, 2015, pp. 24-30.

[22] Martinez del Castillo, Jesús. 2015e. The Speech Act.
International Journal of Language and Linguistics. Special Issue: Linguistics of Saying. Vol. 3, No. 6-1, 2015, pp. 31-38.

[23] Martinez del Castillo, Jesús. 2015f. Determining the Degree of Reality of Language. International Journal of Language and Linguistics. Special Issue: Linguistics of Saying. Vol. 3, No. 6-1, 2015, pp. 39-49.

[24] Martinez del Castillo, Jesús. 2015g. Meaning and Language. International Journal of Language and Linguistics. Special Issue: Linguistics of Saying. Vol. 3, No. 6-1, 2015b, pp. 50-58.

[25] Martinez del Castillo, Jesús. 2015h. The Activity of Speaking. International Journal of Language and Linguistics. Special Issue: Linguistics of Saying. Vol. 3, No. 6-1, 2015, pp. 59-66.

[26] Martinez del Castillo, Jesús. 2015i. Meaning, What Is It. International Journal of Language and Linguistics. Special Issue: Linguistics of Saying. Vol. 3, No. 6-1, 2015, pp. 67-76.

[27] Martinez del Castillo, Jesús. 1015j. Modes of Thinking in Language Study. International Journal of Language and Linguistics. Special Issue: Linguistics of Saying. Vol. 3, No. 6-1, 2015, pp. 77-84.

[28] McArthur, Tom, ed. 1992, The Oxford Companion to the English Language, Oxford University Press.

[29] Onions, C T; W Friedrichsen \& R Burchfield, ed, 1966, The Concise Oxford Dictionary of English Etymology, Oxford University Press.

[30] Ortega y Gasset, José, Ideas y creencias, Alianza Editorial, 1970 [1940].

[31] Ortega y Gasset, José, La idea de principio en Leibniz o la evolución de la teoría deductiva, Alianza Editorial, 1992a [1958].

[32] Ortega y Gasset, José, ¿Qué es conocimiento?, Alianza Editorial, 1992b [1930].

[33] Ortega y Gasset, José, ¿Qué es filosofia? Alianza Editorial 1994 [1957].

[34] Oxford University Press, 1989, The Oxford English Dictionary, Second edition, Prepared by J, A, Simpson and E, S, C, Weiner, 19 vols, Oxford: Clarendon Press.

[35] Partridge, Eric, 1966, Origins, An Etymological Dictionary of Modern English, Londres: Routledge \& Kegan Paul.

[36] Sweet. Henry, Sweet's Anglo-Saxon Primer, Norman Davis, ed. Oxford: Clarendon Press, ${ }^{9} 1970$ (1882) 